\title{
Ischemic Heart Disease in German Immigrants and Their Descendants in a Region of Southern Brazil: A Comparison of Initial Symptoms Reported between two Generations
}

Sergio Luiz Zimmermann, ${ }^{1,2}{ }^{\circledR}$ Miguel Antônio Moretti, ${ }^{1}{ }^{\circledR}$ Caio de Brito Vianna, ${ }^{1}$ Antônio de Pádua Mansur, ${ }^{1}$ Siegmar Starke, ${ }^{3}{ }^{\circledR}$ Luiz Antônio Machado Cesar ${ }^{1}{ }^{\circledR 0}$

Universidade de São Paulo- Instituto do Coração, ${ }^{1}$ São Paulo, SP - Brazil

Hospital Santa Isabel, ${ }^{2}$ Blumenau, SC - Brazil

Hospital Santa Catarina, Blumenau, SC - Brazil

\section{Abstract}

Background: Nothing is known about ischemic heart disease (IHD) in the Germans who emigrated to Brazil during the last century.

Objective: We sought to compare age at diagnosis and IHD manifestations between German immigrants and their first-generation descendants in the region of Blumenau, Brazil.

Methods: We reviewed medical records of hospitals in Blumenau. Comparison of the groups in the evaluation times was made by analysis of variance (ANOVA) with repeated measures, and comparison of two factors was made by two-way ANOVA. The level of significance was set at $\mathrm{p}<0.05$.

Results: Study population comprised 68 patients who were born in Germany (group G) and 99 descendants (group D). Twenty-nine patients of group D had two German parents and 70 had one. Mean age at diagnosis was $66.8 \pm$ 10.6 years, with a significant difference between the groups, four years higher in Group G than group D $(69.0 \pm 8.8$ vs $65.4 \pm 11.5$ years old $)(p=0.025)$. There was no significant difference in risk factors or coronary angiography data between the groups. HDL cholesterol levels were significantly higher in group G than in group D $(48.4 \pm 11.1 \mathrm{mg} /$ $\mathrm{dL}$ vs $43.3 \pm 11.2 \mathrm{mg} / \mathrm{dL}, \mathrm{p}=0.005)$.

Conclusion: At the time of first IHD diagnosis, mean age of the group G was significantly higher than group D, with no differences between groups in sex, risk factors, LDL levels, or clinical and angiographic manifestations. An earlier manifestation of the disease could be part of lifestyle changes in descendants, in this population that mantained eating habits characterized by high saturated fat consumption.

Keywords: Ischemic Heart Disease, Coronary Artery Disease, Germans, Emigration and Immigration, Epidemiology.

\section{Introduction}

International migration has been an important factor in the economic, social, and cultural aspects of several countries. In Brazil, immigration has played an important role in building and modeling a variety of communities, some of which are in confined areas, with their own socioeconomic and cultural behaviors. ${ }^{1}$

Waves of migration from Germany to Brazil occurred primarily during the nineteenth and twentieth centuries and had an impact in the southern region of the country.
These German immigrants formed nuclei first and then cities and have maintained the strong cultural and culinary habits characteristic of their homeland. ${ }^{2}$ One of these communities, and perhaps the most representative one, is the city of Blumenau, located in Itajai valley. Blumenau is a predominantly industrial but also touristic city in the state of Santa Catarina, with a population of 357,199 inhabitants, corresponding to $45.6 \%$ of the population of this region (Itajai valley). ${ }^{2,3}$ The city was founded by Dr. Hermann Otto von Blumenau, a former philosopher and administrator with a doctoral degree in chemistry. 
Studies around the world have explored the incidence and characteristics of ischemic heart disease (IHD) caused by coronary artery disease (CAD) in immigrants. For example, Japanese immigrants living in the USA or in Brazil ${ }^{4-12}$ Italians who migrated to Australia, ${ }^{13}$ Norwegians, Finns, Germans and Hungarians who migrated to Sweden, ${ }^{14}$ and Turkish immigrants living in Germany. ${ }^{15}$

However, no previous study has assessed the German population and their first-generation descendants in Brazil to determine their risk factors for IHD. This would allow the implementation of health actions that would specifically promote good health to these populations. Additionally, such studies could identify changes from traditional habits that may have contributed to increased incidence of specific diseases. The aim of the study was to address relevant consequences of German migration to confined and specific areas in Brazil.

\section{Methods}

We performed a retrospective study of patients with IHD who reside in the Blumenau region. Data were collected from the medical records of hospitals and cardiology clinics in the region. Then we separated patients into two groups, G- Germans and D- descendants.

The diagnosis of IHD was made based on: a) a coronary angiography or a computed tomographic angiography for coronary anatomy showing at least one artery with a lumen obstruction of $\geq 50 \%$ or b) the patient had experienced an acute myocardial infarction (AMI) that was confirmed by electrocardiographic criteria and/ or biochemical markers of myocardial necrosis.

Regarding the clinical data, the time of onset of CAD was defined as the date of the first presentation of IHD recorded in the medical record and/or presence of AMI or angina pectoris. Angina was classified according to the criteria of the Canadian Cardiovascular Society (CCS) ${ }^{16}$ sex and age on the date of the first symptoms were recorded. Diabetes was defined as the use of oral antidiabetic drugs or insulin, and hypertension was defined according to the ESH/ESC Guidelines for managing arterial hypertension. ${ }^{17}$ We determined whether the patient was a smoker at the time they were diagnosed and identified former smokers those who quit smoking at least five years before, and nonsmokers as those who had never smoked. ${ }^{18}$ Low-density lipoprotein (LDL) cholesterol was calculated using the Friedewald formula. In cases in which triglyceride levels were above $400 \mathrm{mg} / \mathrm{dL}$, calculation was performed using the standard lipid profile method. ${ }^{19}$ LDL cholesterol levels were obtained at two time points (baseline and during treatment). Blood samples obtained during acute coronary events, regardless of whether the patient was already using lipid lowering agents, were not considered for analysis. HDL cholesterol levels were directly measured.

\section{Statistical analysis}

All variables were analyzed descriptively. Quantitative variables were expressed as mean and standard deviation. For qualitative variables, absolute and relative frequencies were calculated. The normality of the data was tested using the Kolmogorov-Smirnov test. ${ }^{20}$ For comparison of means between two groups, the unpaired Student's t-test was used. ${ }^{20}$

To test the homogeneity between proportions, the chi-square test $\mathrm{t}^{20}$ or Fisher exact test $\mathrm{t}^{20}$ was used. Comparison of the groups in the evaluation moments was made by analysis of variance (ANOVA) with repeated measures ${ }^{21}$ comparison of two factors was made by two-way ANOVA. ${ }^{20}$ The statistical software used for the calculations was SPSS 21.0. The level of significance was set as $5 \%$.

Sample size was not calculated because this retrospective study aimed to explore an existing and limited population in which all patients who were registered and attended cardiology services in the region were surveyed. They used the same strategy in a previous study comparing Japanese subjects and descendants (nisei) in Brazil ${ }^{22}$ where we found a 10-fold greater probability of an early coronary event in Japanese descendants than in the Japanese group.

\section{Results}

A total of 299 records were obtained; 167 patients were included in the study and separated into two groups: group G, 68 patients $(40.7 \%)$ who had emigrated from Germany, and group D, 99 patients (59.28\%) born to German mothers and/or fathers. The other 132 subjects were excluded for the following reasons: a) not enough data were available in 80 records, b) no data related to IHD were available in 44 records, c) seven patients did not undergo coronary angiography and had no documented AMI, and d) one patient had only temporarily lived in the area (Figure 1) 
The 299 medical records were reviewed from January 2008 to January 2016. Among German immigrants, the earliest diagnosis of IHD was made immigrant in 1981, and the latest record was in 2014. In the German descendants' group, the earliest diagnosis of IHD was made in 1986 and the latest in 2014.

There was no significant difference in sex, smoking status, hypertension, or diabetes between the groups. However, when we divided the populations using age cutoff values for CAD risk ${ }^{23}$ of 55 years for men and 65 years for women, we found significantly older people in group $\mathrm{G}$ than in group D (Table 1). No data regarding smoking were found in seven subjects and no data regarding arterial hypertension were found in two subjects.

There was no significant difference between groups in the occurrence of AMI with or without ST segment elevation, Canadian Cardiovascular Society class of angina, or presence of angina. The first manifestation of IHD was AMI in 72 (43.4\%) of all patients: 39 (39.8\%) in group D and 33 (48.5\%) in group G. Of those with AMI, $67(93.1 \%)$ displayed ST elevation, 35 (89.7\%) in group D and $32(97 \%)$ in group G. No data were obtained regarding $\mathrm{AMI}$ in one subject and regarding angina in three subjects (Table 2).

Baseline LDL values were $159.0 \pm 48.9 \mathrm{mg} / \mathrm{dL}$ in group D and $157.4 \pm 42.9 \mathrm{mg} / \mathrm{dL}$ in group $\mathrm{G}$, and this difference was not statistically significant $(p=0.355)$. When we compared baseline and post-treatment cholesterol measurements between the groups, no statistically differences were found (Table 3). HDL levels, however, were significantly higher in Germans than in descendants $(48.4 \pm 11.1 \mathrm{mg} / \mathrm{dL}$ vs. $43.3 \pm 11.2 \mathrm{mg} /$ $\mathrm{dL} ; \mathrm{p}=0.005)$. No data regarding HDL levels were available in 13 patients.

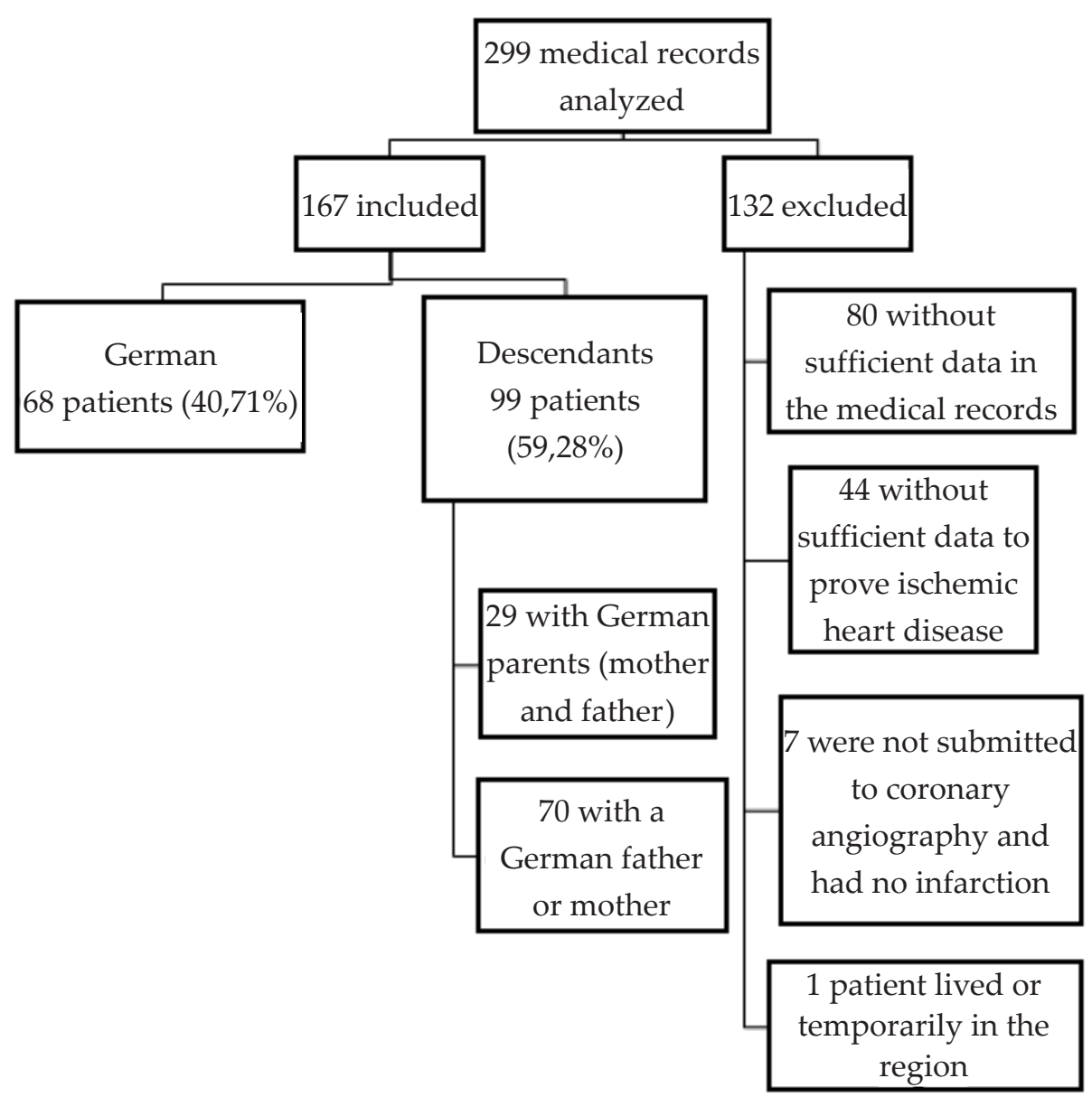


Table 1 - Sex, age, and risk factors in Germans $(n=68)$ and descendants $(n=99)$

\begin{tabular}{|c|c|c|c|c|c|c|c|c|}
\hline \multirow[b]{2}{*}{ Variable } & & \multicolumn{2}{|c|}{ Cohort } & \multicolumn{4}{|c|}{ Group } & \multirow[b]{2}{*}{$\mathrm{p}$} \\
\hline & & \multicolumn{2}{|c|}{$\mathrm{n}=167(\%)$} & \multicolumn{2}{|c|}{$\begin{array}{c}\text { Descendants } \\
n=99(\%)\end{array}$} & \multicolumn{2}{|r|}{$\begin{array}{c}\text { Germans } \\
68(\%)\end{array}$} & \\
\hline \multirow[t]{3}{*}{ Sex } & & & & & & & & 0.137 \\
\hline & Female & 42 & $(25.2)$ & 29 & $(29.3)$ & 13 & (19.1) & \\
\hline & Male & 125 & $(74.8)$ & 70 & $(70.7)$ & 55 & $(80.9)$ & \\
\hline \multirow[t]{3}{*}{ Smoking +} & & & & & & & & 0.371 \\
\hline & No & 127 & (78.9) & 78 & $(81.2)$ & 49 & $(75.4)$ & \\
\hline & Yes & 34 & $(21.1)$ & 18 & $(18.8)$ & 16 & $(24.6)$ & \\
\hline \multirow[t]{3}{*}{ Hypertension } & $\ddagger$ & & & & & & & 0.218 \\
\hline & No & 55 & (33.3) & 29 & $(29.6)$ & 26 & $(38.8)$ & \\
\hline & Yes & 110 & $(66.7)$ & 69 & $(70.4)$ & 41 & $(61.2)$ & \\
\hline \multirow[t]{3}{*}{ Diabetes } & & & & & & & & 0.431 \\
\hline & No & 135 & $(80.8)$ & 82 & $(82.8)$ & 53 & (77.9) & \\
\hline & Yes & 32 & $(19.2)$ & 17 & $(17.2)$ & 15 & $(22.1)$ & \\
\hline \multirow[t]{2}{*}{ Sex/Age } & Male $<55$ and Female $<65$ yo & 36 & $(21.6)$ & 29 & $(29.3)$ & 7 & $(10.3)$ & \\
\hline & Male $\geq 55$ and Female $\geq 65$ yo & 131 & $(78.4)$ & 70 & $(70.7)$ & 61 & $(89.7)$ & 0.003 \\
\hline \multicolumn{9}{|c|}{$\begin{array}{l}{ }^{*} \text { Chi-square test (descriptive statistics) } \\
\text { yo - years old } \\
+ \text { No data available in six subjects } \\
\ddagger \text { No data available in two subjects }\end{array}$} \\
\hline
\end{tabular}

Mean age of all patients at IHD diagnosis was $66.9 \pm$ 10.6 years old (range, $40-90$ years old); $65.4 \pm 11.5$ years old in group $\mathrm{D}$, and $69.0 \pm 8.8$ years old in group $\mathrm{G}$. The difference was statistically significant $(\mathrm{p}=0.025)$, four years on average, as shown in Figure 2 as a normal curve and a cumulative normal curve.

We then sought to determine whether there were associations between age at diagnosis and gender or initial symptoms. We found significant differences by age and sex groups (Table 4). We also evaluated differences in age at diagnosis among descendants according to ancestry, and found that in the 70 descendants with only one German parent, mean age was $64.2 \pm 11.9$ years old, and in the 29 descendants with two German parents, mean age was $68.3 \pm 11.3$ years old $(p=0.02)$.

We did not observe any interaction between age at diagnosis and initial symptoms by sex or other variables ( $p=0.574)$, including interaction between the class of angina and age at diagnosis with IHD.

\section{Discussion}

Previous studies have examined populations that emigrated from other countries to countries in the Americas. This study is the first to explore IHD in German immigrants living outside their country of origin in a confined area in Brazil. This allowed the evaluation of IHD manifestations in German immigrants and their descendants without a strong cultural interference.

An important difference observed between Germans and their descendants was age at the time of the first diagnosis of IHD symptoms. Mean age was four years higher in the first generation of immigrants compared as descendants, even though both populations may have maintained their eating habits and other habits of life.

There was no difference in other IHD characteristics, such as coronary anatomy and disease extension, or the occurrence of AMI with or without ST segment elevation. We did not observe differences between the groups in the incidence of systemic arterial 
Table 2 - Description of clinical presentation according to the study group

\begin{tabular}{|c|c|c|c|c|c|c|c|c|}
\hline & & \multicolumn{2}{|c|}{ Study cohort } & \multicolumn{4}{|c|}{ Group } & \multirow[b]{2}{*}{$\mathrm{p}$} \\
\hline \multicolumn{2}{|l|}{ Variable } & \multicolumn{2}{|c|}{$(n=167)$} & \multicolumn{2}{|c|}{ Descendants (n=99) } & \multicolumn{2}{|c|}{$\begin{array}{c}\text { Germans } \\
(68)\end{array}$} & \\
\hline \multirow[t]{3}{*}{$\begin{array}{l}\text { Acute myocardial } \\
\text { infarction }(\mathrm{AMI}) \ddagger\end{array}$} & & & & & & & & $0.264\left(^{*}\right)$ \\
\hline & No & 94 & $56.6 \%$ & 59 & $60.2 \%$ & 35 & $51.5 \%$ & \\
\hline & Yes & 72 & $40.9 \%$ & 39 & $40.21 \%$ & 33 & $49.25 \%$ & \\
\hline ST elevation AMI & & & & & & & & $0.366(+)$ \\
\hline \multirow[t]{2}{*}{$(n=72)$} & No & 5 & $6.9 \%$ & 4 & $10.3 \%$ & 1 & $3.0 \%$ & \\
\hline & Yes & 67 & $93.1 \%$ & 35 & $89.74 \%$ & 32 & $96.97 \%$ & \\
\hline \multirow[t]{6}{*}{ Angina $\S$} & & & & & & & & $0.526\left(^{*}\right)$ \\
\hline & No & 19 & $11.6 \%$ & 12 & $12.4 \%$ & 7 & $10.5 \%$ & \\
\hline & I & 17 & $10.4 \%$ & 7 & $7.2 \%$ & 10 & $14.9 \%$ & \\
\hline & II & 22 & $13.4 \%$ & 12 & $12.4 \%$ & 10 & $14.9 \%$ & \\
\hline & III & 14 & $8.5 \%$ & 8 & $8.3 \%$ & 6 & $9.0 \%$ & \\
\hline & IV & 92 & $56.1 \%$ & 58 & $59.8 \%$ & 34 & $50.8 \%$ & \\
\hline Development of & & & & & & & & $0.962\left(^{*}\right)$ \\
\hline CF & No & 120 & $71.9 \%$ & 71 & $71.7 \%$ & 49 & $72.1 \%$ & \\
\hline \multicolumn{9}{|c|}{$\begin{array}{l}\text { * Chi-square test } \\
\text { + Fisher's exact test } \\
\text { ¥ No data available in one subject } \\
\text { § No data available in three subjects } \\
\text { CF: Cardiac Failure }\end{array}$} \\
\hline
\end{tabular}

Table 3 - Low-density lipoprotein (LDL)-cholesterol levels by study group and time of assessment

\begin{tabular}{lcc} 
& & Group \\
\hline Time & Descendants & Germans \\
\hline Initial & $158.6+47.8 \mathrm{mg} / \mathrm{dl}$ & $154.9+42.5 \mathrm{mg} / \mathrm{dl}$ \\
\hline Final & $96.9+31.1 \mathrm{mg} / \mathrm{dl}$ & $100.7+39.3 \mathrm{mg} / \mathrm{dl}$ \\
\hline ANOVA with repeated measures: Group ${ }^{*}$ Time, $p=0,355 ;$ Grupo $=0,999 ;$ Time: $p<0,001$ & \\
\hline
\end{tabular}

hypertension, DM and smoking, which would be expected according to other published studies. ${ }^{8,14,24}$ Probably we did not find the same results because our population was concentrated in Blumenau area without major external interferences. Blood test results were also similar, except for HDL cholesterol, which was higher in Germans than their descendants.
Except for the differences we observed in HDL cholesterol levels and age at the first manifestation of disease, no other variable was different in the univariate analysis, so we did not perform a multivariate regression. Such analysis would be justified if we wanted to correct for a confounding factor. We used the analysis of variance of two factors (sex and age) when 


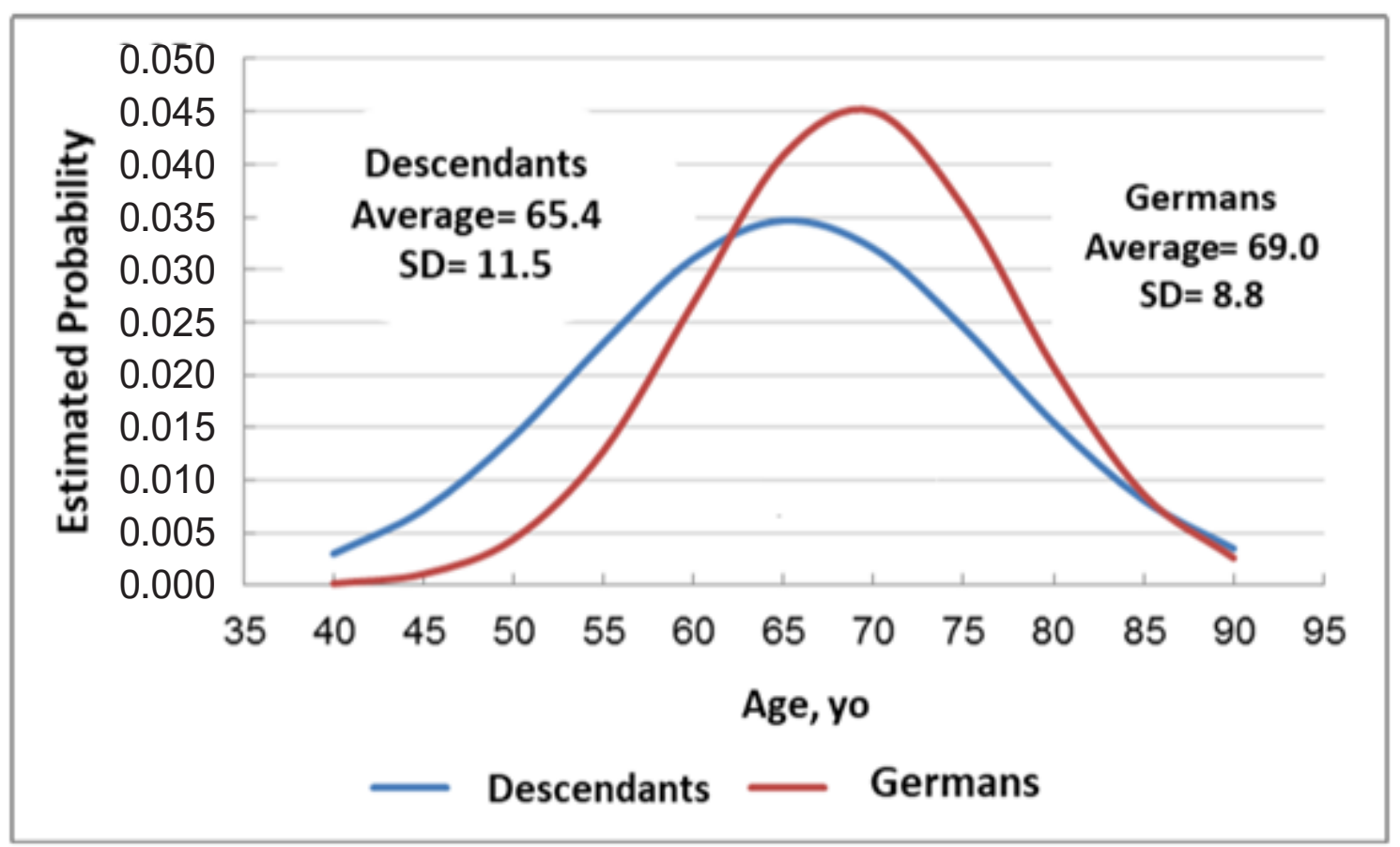

Figure 2 - Distribution of age at diagnosis of coronary heart disease in Germans and descendants

Table 4 - Association of age at diagnosis with study group and sex

\begin{tabular}{lccc}
\hline & Cohort & \multicolumn{2}{c}{ Group } \\
\hline Sex & & Descendants & German \\
\hline Female & $72.2 \pm 10.9$ & $70.7 \pm 11.8$ & $75.5 \pm 8.3$ \\
\hline Male & $65.0 \pm 9.9$ & $63.0 \pm 10.7$ & $67.6 \pm 8.2$ \\
\hline Cohort & & $65.3 \pm 11.5$ & $69.1 \pm 8.8$ \\
\hline Two-factor ANOVA: Group $*$ Sex, $p=0.950 ;$ Group $=0.015$, Sex: $p<0.001$ & & \\
\hline
\end{tabular}

we assessed the relationship of the two variables with the response variable.

In our study, to explain why descendants experienced IHD earlier than German immigrants, one hypothesis is that they seek medical assistance earlier than people from Germany. Perhaps the latter group had difficulties in communication (language), limited access to healthcare, or poor knowledge about how the health system works. Nevertheless, although these factors would be important in IHD diagnosis, they seemed to have low or no impact in our sample, since the number of Germans who presented with myocardial infarction was proportionally similar to that reported in their descendants. In fact, $83 \%$ of the German cohort presented with AMI as the first manifestation of the disease, and we could not determine if the reason for this difference was that they sought help at a later time.

German immigrants had to work hard to survive and build new lives outside their homeland. It is important to note that although they have preserved strong cultural and culinary habits, including a high-fat diet, they presented with IHD at older ages compared with their descendants. Also, health resources were not the same as those disponible for their descendants. To 
explain the significantly higher HDL levels in Germans than descendants, a more intense legwork may have contributed to it.

There are some limitations needed to be addressed. First, in the region of Blumenau, where this survey was performed, periodic floods occur because of intense rains that overflow the rivers. Hence, many patient records were missing, and for this reason, we were unable to include in this cohort a larger number of cases, especially those related to patients who originated from Germany. ${ }^{25}$ Second, the number of patients were small, despite representative of Blumenau population. Third, not all data were available from the medical records of patients, which is seen the variation of " $\mathrm{N}$ " in the tables. Finally, we do not know the age of patients who died from AMI, and therefore we do not know whether Germans died at an early age or had a higher prevalence of cardiovascular risk factors.

\section{Conclusion}

Mean age at the first diagnosis of IHD was four years higher in German immigrants than in the firstgeneration descendants. German patients had higher HDL-cholesterol levels, which may be explained by the fact that these individuals did more legwork than their descendants.

\section{References}

1. Fausto B. Fazer a América: a imigração em massa para a America Latina. São Paulo: EDUSP; 1999.

2. Prefeitura Municipal de Pomerode [Internet]. Pomerode (SC): Prefeitura Municipal; 2020 [cited 2020 May 16]. Available from: www.pomerode. sc.gov.br

3. Instituto Brasileiro de Geografia e Estatística [Internet]. Brasília (DF) IBGE; 2020 [cited 2020 May 16]. Available from: www.ibge.gov.br

4. Gordon T. Mortality experience among the Japanese in the United States, Hawaii, and Japan. Public Health Rep. 1957;72(6):543-53.

5. Gordon T. Further mortality experience among Japanese Americans. Public Health Rep. 1967;82(11):973-84

6. Syme SL, Marmot MG, Kagan A, Kato H, Rhoads G. Epidemiologic studies of coronary heart disease and stroke in Japanese men living in Japan, Hawaii and California: introduction. Am J Epidemiol. 1975;102(6):477-80. doi: 10.1093/oxfordjournals.aje.a112185.

7. Benfante R. Studies of cardiovascular disease and cause-specific mortality trends in Japanese-American men living in Hawaii and risk factor comparisons with other Japanese populations in the Pacific region: a review. Hum Biol. 1992;64(6):791-805.

8. Marmot MG, Syme SL, Kagan A, Kato H, Cohen JB, Belsky J. Epidemiologic studies of coronary heart disease and stroke in Japanese men living in Japan, Hawaii and California: prevalence of coronary and hypertensive heart disease and associated risk factors. Am J Epidemiol 1975;102(6):514-25. doi: 10.1093/oxfordjournals.aje.a112189.

\section{Potential Conflict of Interest}

No potential conflict of interest relevant to this article was reported.

\section{Sources of Funding}

There were no external funding sources for this study.

\section{Study Association}

This article is part of the thesis of Doctoral submitted by Sergio Luiz Zimmermann, from Universidade de São Paulo - INCOR.

\section{Ethics approval and consent to participate}

This article does not contain any studies with human participants or animals performed by any of the authors.

\section{Author contributions}

Conception and design of the research: Zimmermann SL. Cesar, LA. Acquisition of data: Zimmermann SL, Starke S. Analysis and interpretation of the data: Zimmermann,SL. Statistical analysis: Zimmerman SL, Cesar LA. Writing of the manuscript: Zimmermann SL, Moretti MA. Critical revision of the manuscript for intellectual content: Vianna CB, Mansur AP, Cesar LA.

9. Worth RM, Kato H, Rhoads GG, Kagan K, Syme SL. Epidemiologic studies of coronary heart disease and stroke in Japanese men living in Japan, Hawaii and California: mortality. Am J Epidemiol. 1975;102(6):48190. doi: 10.1093/oxfordjournals.aje.a112186.

10. Yano K, MacLean CJ, Reed DM, Shimizu Y, Sasaki H, Kodama K, et al. A comparison of the 12-year mortality and predictive factors of coronary heart disease among Japanese men in Japan and Hawaii. Am J Epidemiol. 1988;127(3):476-87. doi: 10.1093/oxfordjournals.aje.a114824.

11. Robertson TL, Kato H, Rhoads GG, Kagan A, Marmot M, Syme SL, et al. Epidemiologic studies of coronary heart disease and stroke in Japanese men living in Japan, Hawaii and California. Incidence of myocardial infarction and death from coronary heart disease. Am J Cardiol. 1977;39(2):239-43. doi: 10.1016/s0002-9149(77)80197-5.

12. Yano K, Reed DM, McGee DL. Ten-year incidence of coronary heart disease in the Honolulu Heart Program. Relationship to biologic and lifestyle characteristics. Am J Epidemiol. 1984;119(5):653-66. doi: 10.1093/ oxfordjournals.aje.a113787.

13. Armstrong BK, Margetts BM, Masarei JR, Hopkins SM. Coronary risk factors in Italian migrants to Australia. Am J Epidemiol. 1983;118(5):651-8. doi: 10.1093/oxfordjournals.aje.a113676.

14. Gadd M, Johansson SE, Sundquist J, Wändell P. Are there differences in all-cause and coronary heart disease mortality between immigrants in Sweden and in their country of birth? A follow-up study of total populations. BMC Public Health. 2006;6:102. doi: 10.1186/1471-2458-6-102. 
15. Porsch-Oezçueruemez M, Bilgin Y, Wollny M, Gediz A, Arat A, Karatay E, et al. Prevalence of risk factors of coronary heart disease in Turks living in Germany: The Giessen Study. Atherosclerosis. 1999;144(1):185-98. doi: 10.1016/s0021-9150(99)00054-4.

16. Campeau L. Letter: grading of angina pectoris. Circulation. 1976;54(3):522-3.

17. Williams B, Mancia G, Spiering W, Rosei EA, Azizi M, Burnier M, et al. 2018 ESC/ESH Guidelines for the management of arterial hypertension. Eur Heart J. 2018;39(33):3021-104. doi: 10.1093/eurheartj/ehy339.

18. U.S. Department of Health and Human Services, Centers for Disease Control and Prevention, National Center for Chronic Disease Prevention and Health Promotion, Office on Smoking and Health. The 2004 United States surgeon general's report: the health consequences of smoking. NSW Public Health Bull. 2004;15(5-6):107.

19. Martin SS, Blaha MJ, Elshazly MB, Toth PP, Kwiterovich PO, Blumenthal RS, et al. Comparison of a novel method vs the Friedewald equation for estimating low-density lipoprotein cholesterol levels from the standard lipid profile. JAMA. 2013;310(19):2061-8. doi: 10.1001/jama.2013.280532.
20. Rosner B. Fundamentals of biostatistics. 2nd ed. Boston: PWS Publishers; 1986.

21. Timm NH. Multivariate analysis with applications in educations and psychology. Monterrey: Brooks/Cole; 1975

22. Amato RV, César LA, Mansur AP, Hueb WA, Martins JR, Vianna CB, et al. Coronary heart disease clinical manifestation and risk factors in Japanese immigrants and their descendents in the city of São Paulo. Arq Bras Cardiol. 2003;81(3):229-8. doi: 10.1590/s0066-782x2003001100003.

23. Cesar LA, Ferreira JF, Armaganijan D, Gowdak LH, Mansur AP, Bodanese LC, et al. Diretriz de doença coronária estável. Arq Bras Cardiol. 2014;103(2 Suppl 2): 1-59. doi: 10.5935/abc.2014S004.

24. Mizushima S, Moriguchi EH, Ishikawa P, Hekman P, Nara Y, Mimura G, et al. Fish intake and cardiovascular risk among middle-aged Japanese in Japan and Brazil. J Cardiovasc Risk. 1997;4(3):191-9.

25. Zimmermann SL, Starke S, Correa Filho H, Moretti MA, Chagas AC, Timerman S. Increase of prevalence of acute myocardium infarction and sudden death due to the environmental tragedy in south of Brazil. Circulation. 2010:122(Suppl 21)A191. 